
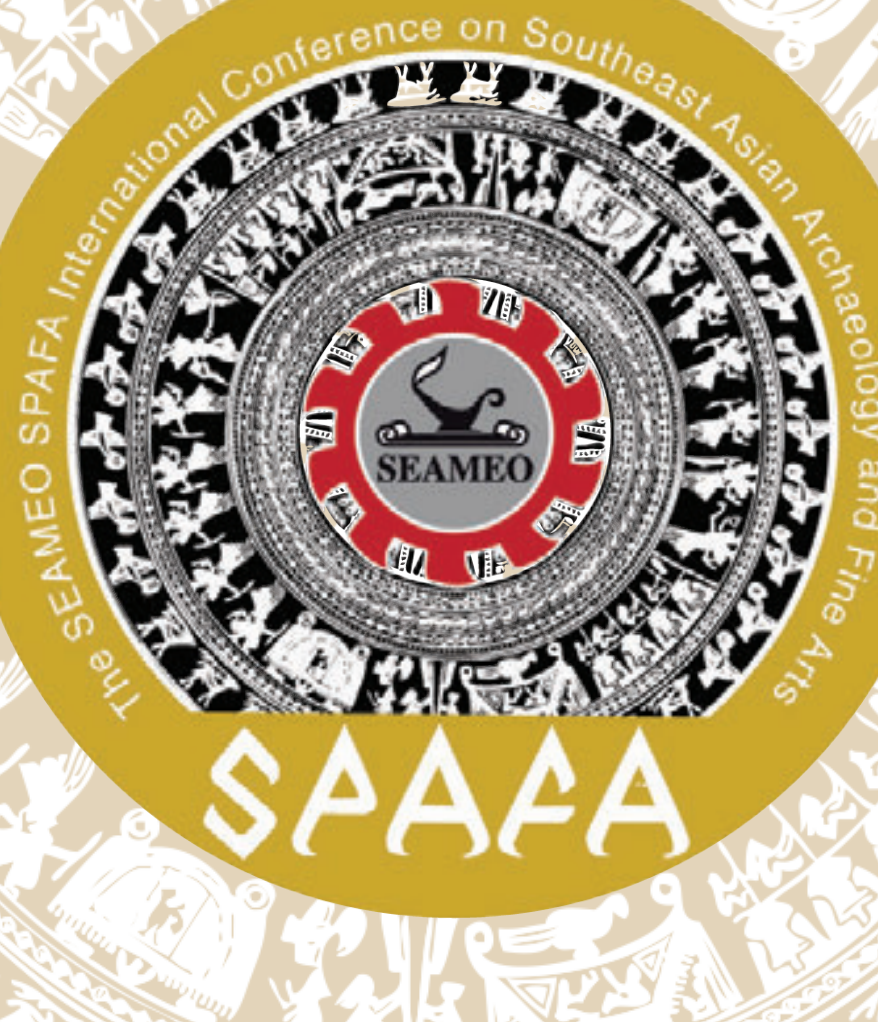
SPAFACON2021 is published by SEAMEO SPAFA, the Regional Centre for Archaeology and Fine Arts established by the Southeast Asian Ministers of Education Organization. SEAMEO SPAFA focusses on archaeology and fine arts in Southeast Asia, and promotes awareness and appreciation of the cultural heritage of the region. Its member-countries are Brunei, Cambodia, Indonesia, Lao PDR, Malaysia, Myanmar, the Philippines, Singapore, Thailand, Timor-Leste, and Vietnam; and its associate member-countries are Australia, Canada, France, Germany, the Netherlands, New Zealand, Spain and the United Kingdom. 


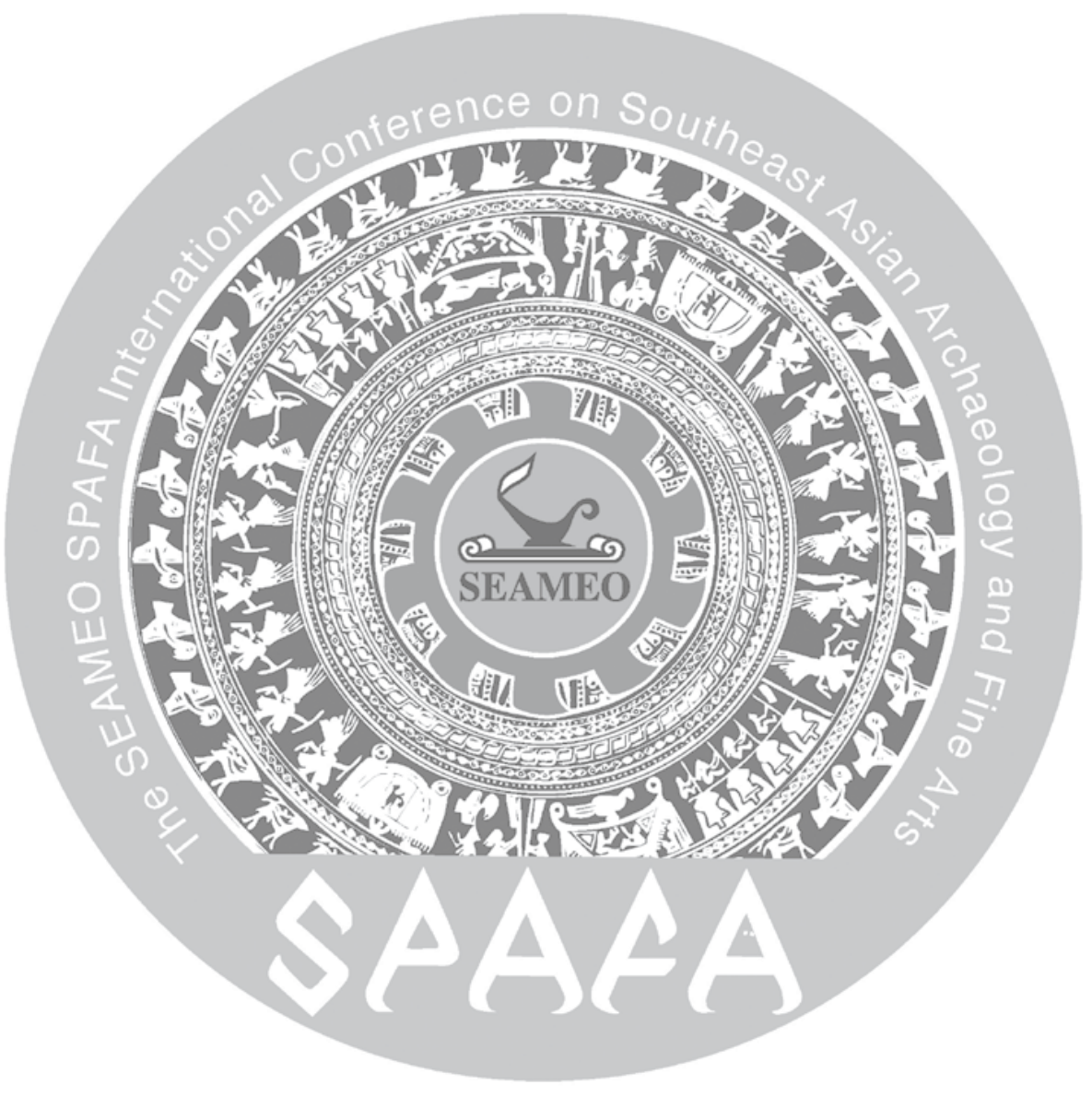

SPAFACON2021

Papers from the SEAMEO SPAFA International Conference on SOUTHEAST ASIAN ARCHAEOLOGY AND FINE ARTS

13 - 17 December 2021

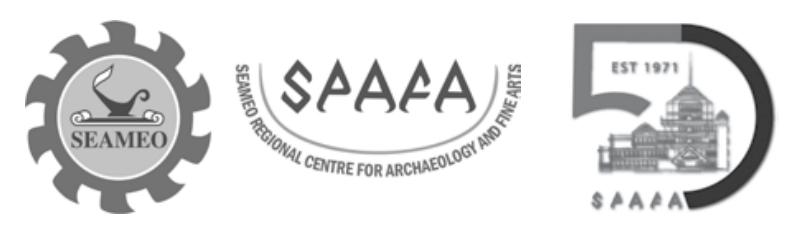


2021 SEAMEO SPAFA

ISBN: 978-616-7961-55-2

ISBN (e-book): 978-616-7961-54-5

DOI 10.26721/spafa.pqcnu8815a

\section{Publisher}

SEAMEO SPAFA Regional Centre for Archaeology and Fine Arts

81/1 Sri Ayutthaya Road, Dusit

Bangkok 10300, Thailand

Tel: +66 (0) 22804022 to 9

Fax: +66 (0) 22804030

www.seameo-spafa.org

E-mail: spafa@seameo-spafa.org

\section{Editor}

Dr Noel Hidalgo Tan

\section{Organizing Committee}

Mrs Somlak Charoenpot

Ms Vassana Kerdsupap

Mr Kanal Khiev

Mr Ean Lee

Ms Gabrielle Anne Mangaser

Dr Hatthaya Siriphatthanakun

Ms Ratchaporn Tesjeeb

Mr Patrick Xia Linhao

Dr Noel Hidalgo Tan

\section{(c) (1) (2)}

Copyright in the volume as a whole is vested in SEAMEO SPAFA, and copyright in the individual chapters also belong to their respective authors and licensed under Creative Commons CC BY-SA 4.0. To view a copy of this license, visit https://creativecommons. org/licenses/by-sa/4.0/

The papers in this publication have not been peer-reviewed and may thus contain preliminary findings, errors, or information that has yet to be endorsed by the relevant academic community. The views expressed in the publication do not necessarily reflect the opinions or policies of SEAMEO SPAFA. 


\section{Title}

\section{CONTENT}

\begin{tabular}{|c|c|c|}
\hline Title & Author & Page \\
\hline \multicolumn{3}{|l|}{ Introduction } \\
\hline $\begin{array}{l}\text { A Historiography of Settlement Archaeology in Southeast } \\
\text { Asia, with Emphasis on the Pre-industrial State Formations }\end{array}$ & Gyles Iannone & 1 \\
\hline $\begin{array}{l}\text { Ocean Imperatives: analysing shipping infrastructure for the } \\
\text { study of maritime networks in Southeast Asia }\end{array}$ & Veronica Walker Vadillo & 17 \\
\hline $\begin{array}{l}\text { Forms of government and local community participation in } \\
\text { the management of cultural World Heritage sites in Southeast } \\
\text { Asia }\end{array}$ & Vithaya Arporn & 24 \\
\hline $\begin{array}{l}\text { Cultural interaction between Việt Nam and Southeast Asian } \\
\text { nations in the } 15^{\text {th }}-16^{\text {th }} \text { centuries: An overview of pottery } \\
\text { items from ancient shipwrecks on display at the Museum of } \\
\text { History in Hồ Chí Minh City }\end{array}$ & $\begin{array}{l}\text { Phạm Ngọc Uyên, } \\
\text { Nguyễn Thị Tú Anh }\end{array}$ & 29 \\
\hline $\begin{array}{l}\text { Sequential Least-Cost Path Sailing Model for Early } 17^{\text {th }} \\
\text { Century South China Sea: Digitally Navigating the Selden } \\
\text { Map of China }\end{array}$ & Wesa Perttola & 40 \\
\hline $\begin{array}{l}\text { The Prevailing Art and Tradition of Intentional Dental } \\
\text { Modification in Prehistoric Southeast Asia }\end{array}$ & Maria Kathryn N. Purnell & 56 \\
\hline $\begin{array}{l}\text { The Still Unexplored Parts of Southeast Asian Archaeology: } \\
\text { Colonial Archaeology Singapore }\end{array}$ & Sxuann Sim & 74 \\
\hline $\begin{array}{l}\text { Khao San Dam: The Archaeological Evidence of Burnt Rice } \\
\text { Festival in Southern Thailand }\end{array}$ & Pakpadee Yukongdi & 83 \\
\hline $\begin{array}{l}\text { Before Bagan: Using Archaeological Data Sets to Assess the } \\
\text { Traditional Historical Narrative }\end{array}$ & $\begin{array}{l}\text { Scott Macrae, Gyles } \\
\text { Iannone, Kong Cheong, } \\
\text { Pyiet Phyo Kyaw }\end{array}$ & 96 \\
\hline The Rock Art in Kinta Valley, West Malaysia: A synthesis & $\begin{array}{l}\text { Chaw Yeh Saw } \\
\text { Hsiao Mei Goh }\end{array}$ & 114 \\
\hline $\begin{array}{l}\text { New Archaeological Discoveries: Gates and Turrets of } 16^{\text {th }} \\
\text { Burmese Royal Capital of Hamsāvatī }\end{array}$ & Thaw Zin Latt & 131 \\
\hline $\begin{array}{l}\text { A preliminary survey of Chinese ceramics in Champa } \\
\text { archaeological sites }\end{array}$ & Do Truong Giang & 148 \\
\hline $\begin{array}{l}\text { A Study on the Structure and Significance of the North } \\
\text { Sanctuary at Western Prasat Top }\end{array}$ & $\begin{array}{l}\text { SATO Yuni, TAMURA } \\
\text { Tomomi, SUGIYAMA } \\
\text { Hiroshi, LAM Sopheak, } \\
\text { SOK Keo Sovannara, } \\
\text { LOEUNG Ravattey, ROS } \\
\text { Visoth }\end{array}$ & 166 \\
\hline The funeral cave of Laang Spean & $\begin{array}{l}\text { Valéry Zeitoun, } \\
\text { Heng Sophady, Hubert } \\
\text { Forestier }\end{array}$ & 173 \\
\hline
\end{tabular}




\begin{tabular}{|c|c|c|}
\hline Title & Author & Page \\
\hline $\begin{array}{l}\text { The Bronze Age People of Ban Kao: A Preliminary Analysis } \\
\text { of the Human Remains from Ban Ta Po Archaeological Site, } \\
\text { Western Thailand }\end{array}$ & $\begin{array}{l}\text { Naruphol } \\
\text { Wangthongchaicharoen, } \\
\text { Supamas Duangsakul, } \\
\text { Pira Venunan, Sukanya } \\
\text { Lertwinitnun, Siriyupon } \\
\text { Tubpenthai }\end{array}$ & 187 \\
\hline The Mt. Popa Watershed and Bagan’s Bronze-Iron Age & Elizabeth Moore & 195 \\
\hline $\begin{array}{l}\text { After } 30 \text { Years and During a Pandemic: Pottery Production } \\
\text { and Distribution in Bagacay, Talibon in the Island of Bohol in } \\
\text { the Philippines }\end{array}$ & $\begin{array}{l}\text { Rhayan Gatbonton } \\
\text { Melendres }\end{array}$ & 205 \\
\hline $\begin{array}{l}\text { Heritage Education in Myanmar - developing resilience and } \\
\text { sustainability through community engagement }\end{array}$ & $\begin{array}{l}\text { Su Su, Win Thant Win } \\
\text { Shwin, Ohnmar Myo, } \\
\text { Charlotte Galloway, } \\
\text { Elizabeth Moore }\end{array}$ & 220 \\
\hline $\begin{array}{l}\text { As my father said: Traditional boatbuilding in Pasuruan, East } \\
\text { Java }\end{array}$ & $\begin{array}{l}\text { Agni Mochtar, Putri } \\
\text { Taniardi, R. Ahmad } \\
\text { Ginanjar Purnawibawa }\end{array}$ & 234 \\
\hline $\begin{array}{l}\text { Tangibility-Intangibility on UNESCO World Heritage } \\
\text { Baroque Philippine Churches: the Spirit of Place and Its } \\
\text { Collective Memory }\end{array}$ & Hee Sook Lee-Niinioja & 241 \\
\hline $\begin{array}{l}\text { Myinkaba village Bagan: The Resilience of Traditional } \\
\text { Knowledge and Culture }\end{array}$ & Theint Aung & 254 \\
\hline $\begin{array}{l}\text { Thai Carpentry Knowledge Transmission: Development of } \\
\text { Traditional Apprenticeships in a New Context }\end{array}$ & Nichamon Hiranpruek & 262 \\
\hline $\begin{array}{l}\text { The Factors of Market Success and Failure of Contemporary } \\
\text { Artists from ASEAN countries }\end{array}$ & Dr Rémy JARRY & 268 \\
\hline $\begin{array}{l}\text { The Forgotten Women: Investigating the Absence of the } \\
\text { Female Artist from Traditionally Male-Centric Southeast } \\
\text { Asian Contemporary Art Historical Narratives }\end{array}$ & Vasanth Narayanan & 279 \\
\hline As One With Nature: Southeast Asian Aesthetic Expressions & Victor R. Savage & 289 \\
\hline $\begin{array}{l}\text { The Series Of Archaeological Dances: A Historical Study and } \\
\text { Dance Moves Recording With Labanotation }\end{array}$ & Dharakorn Chandnasaro & 309 \\
\hline $\begin{array}{l}\text { Musical Instruments on the 16th century bas reliefs in } \\
\text { the North Gallery-East Wing of Angkor Wat : Dating and } \\
\text { Significance }\end{array}$ & Arsenio Nicolas & 324 \\
\hline $\begin{array}{l}\text { Photography in Indonesian Archaeology of the } 19^{\text {th }} \text { to the } \\
\text { Early } 20^{\text {th }} \text { Century }\end{array}$ & $\begin{array}{l}\text { Ahmad Kholdun Ibnu } \\
\text { Sholah }\end{array}$ & 356 \\
\hline $\begin{array}{l}\text { Old Burmese weights were not opium weights. They were } \\
\text { weights. What else do we know about them? }\end{array}$ & Bob Hudson & 369 \\
\hline $\begin{array}{l}\text { Religious Object" Exhibition in the Context of Cultural } \\
\text { Change and Covid-19 Social Distancing (Case studies of } \\
\text { Khmer's Nagar boat in the South of Vietnam) }\end{array}$ & Phạm Thị Thủy Chung & 381 \\
\hline
\end{tabular}




\section{Title}

Author

Page

Creativity and Innovation in Cultural Heritage Management in Plunturan Village, Pulung District, Ponorogo Regency,

Ria Kusuma Wardani, S.Pd.

East Java Province of Indonesia Towards Tourism Village

Beyond the artefact : promoting technology

Cécile de Francquen 407

Indonesian Museum after New Order Regime: The

Representation that Never Disappears

Ayu Dipta Kirana, Fajar

Aji Jiwandono

Geological Museum Innovations to Dealing with Covid-19 Ifan Yoga Pratama Suharyogi, Agustina Djafar, Rahajeng Ayu

Pandemic 


\section{INTRODUCTION}

This volume contains the extended abstracts from the papers presented at the SEAMEO SPAFA International Conference on Southeast Asian Archaeology and Fine Arts, which was held online from 13 to 17 December 2021. Also known as the SPAFACON2021, this conference was organised online due to the pandemic. Despite the disruption brought about by Covid-19 to our in-person events, training programmes and field research, it is heartening to see that archaeology and cultural heritage has continued under new modes of communication and collaboration.

This fourth iteration of the SPAFACON is also scheduled a year earlier than our usual triennial cycle to commemorate the 50th anniversary of SEAMEO initiating a centre dedicated towards archaeology and the fine arts. Over the past year, SPAFA has also been highlighting this legacy of international cooperation and capacity-building by sharing our photographic archives on our social media.

I am delighted by the high level of enthusiasm and intellectual curiosity brought by the participants to the conference. During our call for papers we received close to 90 submissions, but owing to the pressures of time and the online format, we were only able to accept 34 papers for the conference. The variety of papers present here, although a small set compared with our usual proceedings, reflects the breadth of the centre's ambit covering not just archaeology, but also performing arts, visual arts, museum studies, and other aspects of Southeast Asian cultural heritage.

I would like to thank all the participants, without whom this conference would not be possible in its present form, in particular, our Governing Board members who represent every country in Southeast Asia, and to the Ministry of Culture, Thailand and the Ministry of Education, Thailand for their long-standing support of SEAMEO SPAFA and its activities.

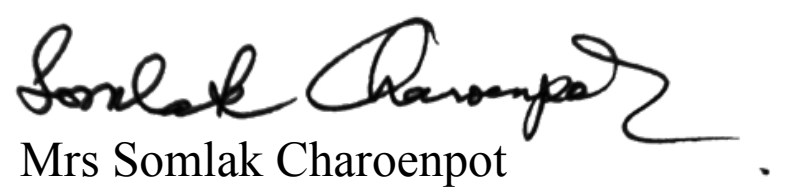

Centre Director

SEAMEO SPAFA 


\title{
The Prevailing Art and Tradition of Intentional Dental Modification in Prehistoric Southeast Asia Ang Namamayaning Sining at Tradisyon ng Intensyonal na Modipikasyon ng Ngipin sa Sinaunang Timog-Silangang Asya
}

\author{
10792/pqcnu8815a-06 \\ Maria Kathryn N. Purnell \\ Archaeological Studies Program, University of the Philippines \\ mnpurnell@up.edu.ph
}

\begin{abstract}
Since prehistoric times, humans have changed select characteristics of their bodies, such as tattooing, hair-dyeing, cranial and feet deforming, and teeth modifying. Teeth are some of the most well-preserved remains in the archaeological record, with which we can study past cultural and ritualistic beliefs. Previous publications on dental modifications in Southeast Asia are mostly limited to the mainland, thus this paper reviews modifications observed in prehistoric sites across Southeast Asia, identifying common techniques and motivations. Findings show occurrence of dental ablation, filing, plating, and coloration, which began in the Neolithic, disappeared in the Bronze Age, but reappeared in the Iron Age, although the absence may be due to sampling shortage. Modifications have been associated to aestheticism, group identity, rite of passage, practicality, and medical benefit, but whether these all ring true remains uncertain. It is recommended that future research expand scope for better data representation, analyze modifications with context of community profiles, and investigate the significance of migration in the prevalence of certain techniques and patterns as part of understanding the cultural aspects of past humans' lives, and assess the cultural (dis)continuity of these traditions into modern-day forms of body modification, art, healing, self-expression, and identity.
\end{abstract}

Magmula sinaunang panahon, maitatala ang mga pagbabagong pisikal sa katawan, tulad ng pagtatato, pagkukulay ng buhok, at pag-iiba-anyo ng ulo, paa, at ngipin. Nabibilang ang ngipin sa mga lubos na napepreserbang artepakto sa arkiyoloji, at sa gayo'y magagamit pang-aral ng mga nakalipas na kultura at ritwal. Kasalukuyang limitado sa mainland ng Timog-Silangang Asya ang saliksik sa intensyonal na modipikasyon ng ngipin, kaya tatalakayin dito ang mga sinaunang modipikasyong nabanggit sa buong rehiyon, at tutukuyin ang pagkakatulad sa mga teknik at motibasyon. Nagsimula ang paglaganap ng sadyang pagtatanggal, pagliliha, pagkakalupkop, at pagkukulay ng ngipin noong Panahong 
Neolitiko, naglaho noong Panahong Tanso, at bumalik muli pagsapit ng Panahong Bakal, ngunit maaaring iukol ang paglaho sa kakulangan ng datos. Hindi pa tiyak, pero pwedeng ang mga modipkasyon sa estetisismo, pakikisama, pagriritwal, praktikalidad, at benepisyong-medikal. Inirerekomendang palawakin sa susunod na saliksik ang sakop para sa mas mabuting representasyon ng datos, suriin ang mga modipikasyon sa konteksto ng komunidad, at imbestigahan ang kahalagahan ng migrasyon sa paglaganap ng mga partikular na teknik at padron habang inuunawa ang mga aspetong kultural ng sinaunang panahon, at tasahan ang pagpapatuloy (o hindi) ng mga tradisyong nabanggit sa kasalukuyang modipikasyon ng katawan, sining, paggagamot, pagpapahayag ng sarili, at identidad.

\section{Keywords}

intentional dental modification; Southeast Asia; prehistoric dentition; bioarchaeology; intensyonal na modipikasyon ng ngipin; Timog-Silangang Asya; sinaunang kondisyon ng mga ngipin; biyoarkiyoloji

\section{Dental Modification and Archaeology}

In a study of pre-Columbian Mexico societies, Fastlicht (1948) noted how humans have historically "... always shown a tendency to embellish themselves by deforming or changing the characteristics of their bodies." (p. 315); even in modern times, humans continue to modify select parts of their bodies (Kinaston et al. 2020). These can occur anywhere on the body, such as tattooing on the skin, deformation or reshaping of the cranium or feet, perforating the nose, lip, or ear, as well as modifying human dentition (Barnes 2010).

Dental modification refers to changes that the teeth undergo or are observed to have. As per Mower (1999), these modifications can either be passive (unintentional), or active (intentional). Unintentional forms of dental modification include the wearing of the tooth due to consuming food or due to using the tooth as a tool for daily activities (Scott and Turner 1988, from Barnes 2010), these occur whether or not an individual intends for their teeth to change in form or shape.

Active forms of dental modification on the other hand are more varied, and can be done through the likes of chipping, filing, coloring or dyeing, inlaying, or removing the teeth (Mower 1999; Fastlicht 1948). Chipping can be observed by cracks that form on the surface on the tooth, affecting enamel (and in some more extreme cases, the dentine as well) (Bonfiglioli et al. 2004), although this often occurs more often in passive dental modifications. Filing refers to using sharp objects to reshape the canines and incisors, 
either to a pointed shape or conversely to remove their pointedness, which can be done extremely enough to expose the dentine (Mower 1999). Coloring, dyeing, and staining of the teeth are usually done by applying mixtures of select plants with the necessary coloring properties, which more often than not also contained beneficial medical properties (Zumbroich 2011); this practice is conducted by some to distinguish human identity from white-toothed animals (Mower 1999). Drilling on the tooth surface to form holes is called inlaying. Some societies also place metal ornaments on the teeth as part of the modification practice (Atienza 2014; Jones 2001; Mower 1990). Lastly, the removing of select teeth (again, often the incisors and canines) is also known as tooth ablation - this practice can be done with either deciduous or permanent teeth (Mower 1990). There are various reasons that can explain why communities choose to intentionally modify, or "transfigure", as Jones (2001) puts it, but they usually boil down to either medical (i.e., pain alleviation, prophylaxis) or socio-cultural reasons (i.e., social status, group identity, ritual and lifestage markers, beauty standards) (Mower 1999; González et al. 2010; Smith-Guzman et al. 2020; Domett et al. 2011; Koesbardiati et al. 2015; Zumbroich 2011; Ichord 2000, from Barnes 2010).

Given this, studying intentional dental modification practices help us understand some aspects of cultural traditions not just of past societies, but of present-day ones as well, and identify if any of these practices have been passed down generations over time - and if changes have been added or removed as well (Smith-Guzman et al. 2020; González et al. 2010). Studies of dental modification have also been used to determine handedness preference for eating and tool use, as seen in Middle Pleistocene hominid samples excavated in Atapuerca, Spain (De Castro 1988).

Studies of intentional dental modification are best done holistically, that is, as a collaboration of different disciplines filling in one another's potential gaps to form a full story; these include anthropology, archaeology, chemistry, and ethnobotany, to name a few. Teeth are some of the most durable and well-preserved bone that can be recovered in archaeological sites (McKay et al. 2013), thus they make up a significant area of study within bioarchaeology. Together with other fields of research, questions on cultural practices, ancient population health, and social status and stratification can be answered (Mower 1999; McKay et al. 2013; Smith-Guzman et al. 2020; Newton and Domett 2017; Zumbroich 2011). 
This paper in particular looks at documentation of intentional dental modification practices throughout Southeast Asia during the prehistoric period and how this reflects in the cultures and societies in which they were observed. From here it is hoped to provide an initial summary of modification patterns and trends in the region, which while there is growing supply of research for especially in recent years has yet to be compiled into one publication.

\section{A History of Intentional Dental Modification as a Practice}

Various forms of intentional dental modification practices have been documented in different periods of time, and in different sites across the globe. Dental modification has been observed in remains as old as the epi-Paleolithic period, in the Taforalt necropolis site found in Morocco (Bonfiglioli et al. 2004). The individuals observed here are dated to a range of $11,900 \pm 240$ years ago (y.a.), and $10,800 \pm 400$ y.a. The dental modifications found were a mix of active and passive intentions: some had anterior teeth removed (also called avulsion) which then transitioned mastication tooth wear and stress from the anterior teeth (incisors and canines) to the posterior teeth (premolars and molars), but notching modifications were found likely caused by use of the teeth as assistive tools in their daily tasks or activities.

Barnes (2010) notes the earliest record of intentional dental modification for aesthetic or beauty purposes to the Etruscans in seventh century BCE. Etruscan women wore gold appliances used to either hold teeth in place or to insert a fake tooth, similar to modernday braces and dentures, both for medical and for aesthetic reasons.

In the Neolithic period, dental modification has been observed in teeth samples from Mehrgarh, Pakistan dated to approximately 7500-9000 years ago (Coppa et al. 2006). In particular, the remains were found to have drilled permanent crowns, although it is suggested this was more for medical reasons than aesthetics - an early form of dentistry, if you will.

A summary of other records of dental modification practices over the centuries is found in Barnes (2010), including gold plating and artificial teeth in Ancient Rome, dental filing and inlaying among pre-Columbian societies, tooth coloring in ancient Japan, and the use of false teeth among elites of $17^{\text {th }}$ century England and $18^{\text {th }}$ century France. 
Smith-Guzman et al. (2020) recently published a paper on intentional dental modification practices found among African-originated individuals in Panama. The teeth filing and chipping patterns they observed in some individuals were deemed consistent with practices also observed in Sub-Saharan Africa, and isotope analysis revealed that some of the buried remains in the site had migrated to Panama at adolescent age and died only a few years after. This study also discussed the impact of European colonization and the slave trade industry imposed on colonization of the African continent. This study also underscored the use of analyzing strontium isotopes in teeth to pinpoint migration patterns, a method also applied to understanding the frequent movements of people from the Chiribaya of Southern Peru (Knudson and Buikstra 2007), as well as distinguishing modification patterns of migrants and the Jomon of Japan (Kusaka et al. 2009).

Although perhaps not in the exact same methods, intentional modification of the teeth is a practice still seen in society today. Modern dentistry makes use of retainers and braces to align the teeth; aligned teeth are viewed as attractive by today's beauty standards. Some indigenous tribes also still practice teeth removal, mostly for medical (i.e., lockjaw workaround) reasons, like with the Maasai of Tanzania (Barnes 2010).

Ethnographic and archaeological studies have been published of communities practicing intentional dental modification in different parts of at least Southeast Asia (Rittershofer 1937; Zumbroich 2011; Koesbardiati et al. 2015; Domett et al. 2011; Newton and Domett 2017; Jones 2001) and South Asia (Coppa et al. 2006), South America and Africa (SmithGuzmán et al. 2020, Bonfiglioli et al. 2004; Mower 1999), and Europe (De Castro et al. 1988).

\section{Intentional Dental Modification in Southeast Asia}

This review will look at practices of intentional dental modification in both mainland and island Southeast Asia, later identifying common trends and unique distinctions of patterns and methods across the region. To date, there is no solid evidence for how intentional dental modification practices started out in Southeast Asia. The ongoing prevalent theory is that it was passed down from southern China and Taiwan in the Neolithic; the earliest evidence of tooth ablation in Neolithic East Asia is found in sites within China dated to around 6500 years ago (Han and Nakahashi 1996, from Kinaston et al. 2020). From there, the cultural practice was introduced to different communities in Vietnam, Thailand, Cambodia, and Indonesia (Newton and Domett 2017; Kinaston 2020; Domett et al. 2011). 


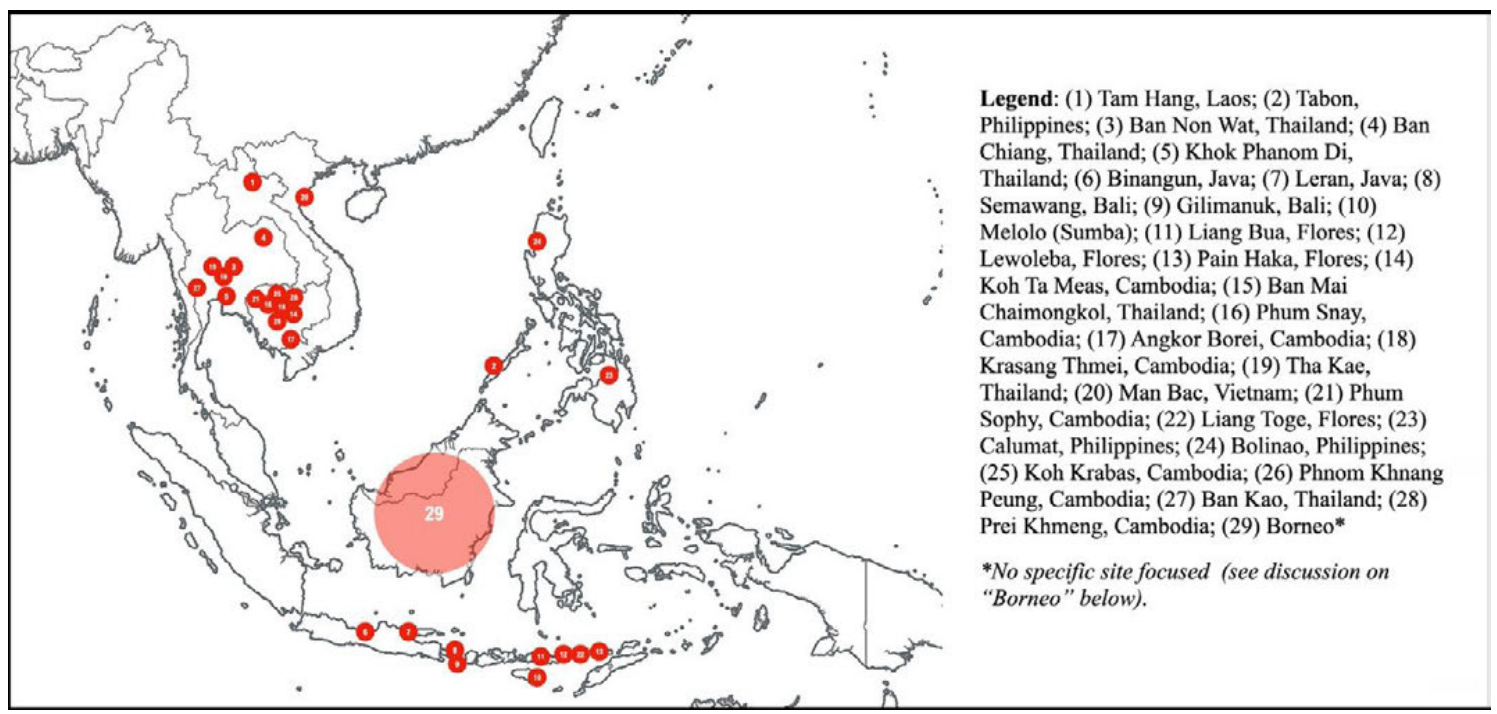

Fig 1. Map of SEA with pins on site locations with intentional dental modification as discussed here. Source: Blank map template from ASEAN UP (2018).

While extensive studies have been made throughout the region (see Figure 1), there are still some territories for which literature on intentional dental modification was not included or could not be found. Nonetheless it is believed the provided data is still a sufficient starting point for discussion on the observation of these cultural practices in prehistoric Southeast Asia. A summary of sites mentioned in this section are found in Figure 2 below, arranged in order of oldest to most recent date, although in some geographic locations there are no specific sites are mentioned for their evidence of intentional dental modification.

\begin{tabular}{|c|c|c|c|c|}
\hline \multicolumn{5}{|c|}{ SITES IN (PRE)HISTORIC SOUTHEAST ASIA WITH EVIDENCE OF } \\
INTENTIONAL DENTAL MODIFICATION
\end{tabular}




\begin{tabular}{|c|c|c|c|c|}
\hline $\begin{array}{c}\text { Khok } \\
\text { Phanom Di }\end{array}$ & Ablation & Thailand & $\begin{array}{c}\text { Neolithic } \\
\text { (c. 2050-1550 BCE) }\end{array}$ & $\begin{array}{l}\text { Palefsky 2019; } \\
\text { Newton and } \\
\text { Domett } 2017\end{array}$ \\
\hline Binangun & Sharpening & $\begin{array}{l}\text { Indonesia } \\
\text { (Java) }\end{array}$ & $\begin{array}{l}\text { Neolithic-Iron (c. } \\
1550 \text { BCE-450 CE) }\end{array}$ & $\begin{array}{c}\text { Koesbardiati et al. } \\
2015\end{array}$ \\
\hline Leran & Sharpening & $\begin{array}{c}\text { Indonesia } \\
\text { (Java) }\end{array}$ & $\begin{array}{c}\text { Neolithic-Iron (c. } \\
1550 \text { BCE-450 CE) }\end{array}$ & $\begin{array}{c}\text { Koesbardiati et al. } \\
2015\end{array}$ \\
\hline Semawang & $\begin{array}{l}\text { Sharpening, } \\
\text { Filing }\end{array}$ & $\begin{array}{l}\text { Indonesia } \\
\text { (Bali) }\end{array}$ & $\begin{array}{l}\text { Neolithic-Iron (c. } \\
1550 \text { BCE-450 CE) }\end{array}$ & $\begin{array}{c}\text { Koesbardiati et al. } \\
2015\end{array}$ \\
\hline Gilimanuk & Filing & $\begin{array}{l}\text { Indonesia } \\
\text { (Bali) }\end{array}$ & $\begin{array}{l}\text { Neolithic-Iron (c. } \\
1550 \text { BCE-450 CE) }\end{array}$ & $\begin{array}{c}\text { Koesbardiati et al. } \\
2015\end{array}$ \\
\hline Melolo & Ablation & $\begin{array}{l}\text { Indonesia } \\
\text { (Sumba) }\end{array}$ & $\begin{array}{l}\text { Neolithic-Iron (c. } \\
1550 \text { BCE-450 CE) }\end{array}$ & $\begin{array}{l}\text { Koesbardiati et al. } \\
\text { 2015; Kinaston et } \\
\text { al. } 2020\end{array}$ \\
\hline Liang Bua & Ablation & $\begin{array}{l}\text { Indonesia } \\
\text { (Flores) }\end{array}$ & $\begin{array}{l}\text { Neolithic-Iron } \\
\text { (c. } 800-550 \mathrm{BCE} \text { ) }\end{array}$ & $\begin{array}{c}\text { Koesbardiati et al. } \\
\text { 2015; Kinaston et } \\
\text { al. } 2020\end{array}$ \\
\hline Lewoleba & Ablation & $\begin{array}{l}\text { Indonesia } \\
\text { (Flores) }\end{array}$ & $\begin{array}{l}\text { Neolithic-Iron (c. } \\
1550 \text { BCE-450 CE) }\end{array}$ & $\begin{array}{l}\text { Koesbardiati et al. } \\
\text { 2015; Kinaston et } \\
\text { al. } 2020\end{array}$ \\
\hline Pain Haka & Ablation & $\begin{array}{l}\text { Indonesia } \\
\text { (Flores) }\end{array}$ & $\begin{array}{c}\text { Neolithic } \\
\text { (c. 1053-207 BCE) }\end{array}$ & $\begin{array}{c}\text { Kinaston et al. } \\
2020\end{array}$ \\
\hline Koh Ta Meas & Ablation & Cambodia & $\begin{array}{c}\text { Neolithic } \\
\text { (c. } 1050 \text { BCE) }\end{array}$ & $\begin{array}{c}\text { Newton and } \\
\text { Domett 2017; } \\
\text { Domett et al. } 2011\end{array}$ \\
\hline Koh Krabas & Ablation & Cambodia & $\begin{array}{c}\text { Neolithic } \\
\text { (c. } 980-860 \text { BCE) }\end{array}$ & $\begin{array}{l}\text { Newton and } \\
\text { Domett } 2017\end{array}$ \\
\hline $\begin{array}{c}\text { Ban Mai } \\
\text { Chaimongkol }\end{array}$ & Ablation & Thailand & $\begin{array}{l}\text { Neolithic to Iron } \\
\text { (c. 640-400 BCE) }\end{array}$ & Palefsky 2019 \\
\hline Man Bac & Ablation & Vietnam & $\begin{array}{c}\text { Neolithic } \\
(2000-1500 \text { BCE })\end{array}$ & $\begin{array}{l}\text { Newton 2014; } \\
\text { Newton and } \\
\text { Domett } 2017\end{array}$ \\
\hline Ban Kao & $\begin{array}{l}\text { Ablation; } \\
\text { Filing }\end{array}$ & Thailand & $\begin{array}{c}\text { Neolithic (no } \\
\text { specific date stated) }\end{array}$ & $\begin{array}{c}\text { Newton and } \\
\text { Domett } 2017 \\
\end{array}$ \\
\hline Phum Snay & $\begin{array}{l}\text { Ablation, } \\
\text { Filing }\end{array}$ & Cambodia & $\begin{array}{c}\text { Iron (c. } 550 \mathrm{BCE} \\
-450 \mathrm{CE})\end{array}$ & $\begin{array}{c}\text { Newton and } \\
\text { Domett 2017; } \\
\text { Domett et al. } 2011\end{array}$ \\
\hline
\end{tabular}




\begin{tabular}{|c|c|c|c|c|}
\hline Phum Sophy & $\begin{array}{l}\text { Ablation, } \\
\text { Filing }\end{array}$ & Cambodia & $\begin{array}{l}\text { Iron (c. } 550 \text { BCE- } \\
\quad 450 \mathrm{CE})\end{array}$ & $\begin{array}{c}\text { Newton and } \\
\text { Domett 2017; } \\
\text { Domett et al. } 2011\end{array}$ \\
\hline Angkor Borei & Filing & Cambodia & $\begin{array}{l}\text { Iron (c. } 200 \mathrm{BCE} \\
-200 \mathrm{CE})\end{array}$ & $\begin{array}{c}\text { Newton 2014; } \\
\text { Newton and } \\
\text { Domett } 2017\end{array}$ \\
\hline $\begin{array}{l}\text { Krasang } \\
\text { Thmei }\end{array}$ & Ablation & Cambodia & $\begin{array}{l}\text { Iron (c. } 100 \text { BCE- } \\
290 \mathrm{CE})\end{array}$ & $\begin{array}{c}\text { Newton and } \\
\text { Domett 2017; } \\
\text { Domett et al. } 2011\end{array}$ \\
\hline Tha Kae & Ablation & Thailand & $\begin{array}{c}\text { Iron (c. } 100 \mathrm{BCE} \\
-400 \mathrm{CE})\end{array}$ & Palefsky 2019 \\
\hline Prei Khmeng & Filing & Cambodia & $\begin{array}{c}\text { Iron (no specific } \\
\text { date stated) }\end{array}$ & $\begin{array}{l}\text { Newton and } \\
\text { Domett } 2017\end{array}$ \\
\hline Liang Toge & Filing & $\begin{array}{l}\text { Indonesia } \\
\text { (Flores) }\end{array}$ & $\begin{array}{l}\text { Age of Contact (c. } \\
\text { 884-1164 CE) }\end{array}$ & $\begin{array}{c}\text { Kinaston et al. } \\
\text { 2020; Koesbardiati } \\
\text { et al. } 2015\end{array}$ \\
\hline Calumat & Gold Plating & Philippines & $\begin{array}{c}\text { Age of Contact (c. } \\
890-987 \text { CE) }\end{array}$ & $\begin{array}{c}\text { Bernardo } \\
\text { (Unpublished) }\end{array}$ \\
\hline Bolinao & Gold Plating & Philippines & $\begin{array}{c}\text { Age of Contact (c. } \\
\text { 1300-1500 CE) }\end{array}$ & Atienza 2014 \\
\hline $\begin{array}{l}\text { Phnom } \\
\text { Khnang } \\
\text { Peung }\end{array}$ & Ablation & Cambodia & $\begin{array}{l}\text { Age of Contact (c. } \\
1500-1700 \mathrm{CE} \text { ) }\end{array}$ & $\begin{array}{l}\text { Newton and } \\
\text { Domett } 2017\end{array}$ \\
\hline
\end{tabular}

Fig 2. Summary of sites in prehistoric Southeast Asia with evidence of intentional dental modification mentioned in the text.

\section{Mainland Southeast Asia}

\section{Cambodia}

Although the research available for intentional dental modification in Cambodia encompasses several sites, many of these contained small sample sizes. Perhaps the most extensive research undertaken is of two sites in particular: Phum Snay and Phum Sophy (Domett et al. 2011; Newton and Domett 2017). For both sites, dental ablation and dental filing were observed, although the sample size of the former is far more than of the latter. Of maxillary dentition, the most common tooth removed at Phum Snay and Phum Sophy was the lateral incisors, followed by the canine teeth; in mandibular dentition however, all four incisors were frequently removed (Domett et al. 2011). Analysis of the samples suggests that dental ablation as a practice was conducted on individuals as early as young 
adulthood, perhaps siginifying a significant life-stage to celebrate. With filing, patterns varied on affected teeth both on the maxillary and the mandibular dentition of both sites; at Phum Sophy, all individuals affected had filed canines, but this was not the same pattern is at Phum Snay (Domett et al. 2011). Generally, however, the limited evidence reveals no significant influence of age or sex to determine who is treated with the dental modification (Newton and Domett 2017).

Records of intentional dental ablation have also been observed in other Cambodia sites, such as Koh Krabas (maxillary lateral incisors), Krasang Thmei (all mandibular incisors, although poor preservation suggests this may be pathological loss instead), Koh Ta Meas (maxillary lateral incisors and canines), Phnom Khang Peung (maxillary lateral incisors and canines), and Prei Khmeng (Domett et al. 2011; Newton and Domett 2017), but most of the samples here only had around one or two individuals, save for Koh Krabas (10 individuals) and Phnom Khnang Peung (seven individuals). Interestingly enough, the remains observed to have ablation in Bronze Age site Koh Ta Meas were all middle-aged women, suggesting a possible demographic preference (Newton and Domett 2017).

Meanwhile, dental filing has been observed in remains from Prei Khmeng (incisors, canines, and premolars) and Angkor Borei (incisors and canines filed to points) (Newton and Domett 2017).

Identifying the specific motivations for why Cambodian prehistoric societies partake in intentional dental modification is still hazy, but suggested theories include association with status within the group, celebration of important life stages (i.e., puberty, marriage, mourning), as well as conforming to set beauty standards of the time (Domett et al. 2011).

\section{Laos}

Until recently (Kinaston et al. 2020), the rock-shelter site of Tam Hang in Laos was previously thought to contain the earliest evidence of intentional ablation in Southeast Asia and in the Late Pleistocene of the eastern Old World (Palefsky 2019; Newton and Domett 2017; Willman et al. 2016). At present, the site is now dated much later to the Neolithic (c. 2550 BCE). In any case, Tam Hang remains the only known site in Laos with evidence of intentional dental modification. Although the site returned a very small sample size (seven individuals in total), they display a good range of ablation states, from zero (or absence of ablation) to four incisors extracted. It is still up for debate what purpose there is for the intentional dental modification observed here. 


\section{Thailand}

The most extensive evidence of intentional dental modification here is found in Khok Phanom Di (c. 2050-1550 BCE), where ablation was observed in over 70 per cent of the recovered remains, some of which included individuals aged 9-12 years old. In total, 13 different patterns of dental ablations were found, and the affected teeth varied temporally: in earlier burials, maxillary lateral incisors were extracted, but in later burials it was the maxillary central incisors and all mandibular incisors (Newton and Domett 2017; Domett et al. 2011; Palefsky 2019).

Aside from Khok Phanom Di, dental ablation was also found in Ban Chiang (central incisors), Ban Kao (roughly half of the recovered remains had extracted upper lateral incisors and canines), Ban Non Wat (six individuals with extracted upper lateral incisors and canines), and Ban Lum Khao (one individual lacking lower central incisors) (Newton and Domett 2017). Identifying ablation in samples from Noen U-Loke has been difficult given the mix of agenesis (Domett et al. 2011; Newton and Domett 2017).

A more recent publication by Palefsky (2019) detailed cases of dental ablation found in two Iron Age sites in central Thailand: Ban Mai Chaimongkol, and Tha Kae. Ablation was observed in more individuals from the latter $(\sim 67$ per cent) than the former $(\sim 17$ per cent). No correlation was found between these ablation practices and sex, age, or mortuary contexts, although Palefsky concedes that this may be due to the limited sample size available.

Traces of dental filing have also been seen in Ban Kao, particularly in the labial surface of the upper incisors, however the lack of visible filing pattern or symmetry across filed individuals suggests that this was not intentional (Newton and Domett 2017).

\section{Vietnam}

The only evidence of dental ablation found in Neolithic Vietnam is in Man Bac, particularly the extraction of upper lateral incisors (Newton and Domett 2017). Da But, another Neolithic site, also contains evidence of anterior ante-mortem tooth loss, however it is unclear if this is due to intentional removal (ablation) or because the teeth were used as tools, i.e., "third hand" (Domett et al. 2011). 


\section{Island Southeast Asia}

Borneo

Literature of intentional dental modification in Borneo is limited to ethnographic and historic accounts of travelers, not archaeological research (Jones 2001). Four methods of dental modification have been observed in the various indigent groups residing in Borneo: filing, wiring and inlaying, plating, and ablation. In some instances, coloring or staining of the teeth is done in conjunction with filing, as well as with wiring and inlaying. How these are carried out (i.e., process, ingredients, and design) is unique to each group. The motives behind the practice also vary, but include marking important life-stages (e.g., puberty, preparation for war), functionality (e.g., stronger use of hunting blow-pipe), and oral prophylaxis (e.g., modified feeding mechanism in case of lockjaw).

\section{Indonesia}

An initial review of dental modifications in prehistoric populations in Indonesia by Koesbardiati et al. (2015) observed dental filing, sharpening, extraction, and coloring (using betel nut) techniques in sites on the islands of Java, Bali, Sumba, and Flores. Specific to the Flores is the technique of extracting the maxillary lateral incisors, which the authors suggested were either the oldest form of intentional dental modification in the geographic area, or were an island-specific isolated innovation, as this form of dental ablation was not found in other sites. Dental filing, on the other hand, is still carried out in some societies today, associated with ritual beliefs (Bali) and aestheticism (Timor).

A more recent study by Kinaston et al. (2020) meanwhile examined the tradition of dental ablation in select sites in Eastern Indonesia, as well as one Lapita-associated site in Vanuatu of the Pacific Islands. Assessment of the samples returned results the tooth loss was intentional, and fourteen different patterns of ablation were identified. The widespread practice of dental ablation in prehistoric Eastern Indonesia was suggested to be connected with the expansion and migration of Austronesian-speaking populations across the region, in which dental ablation as a practice was one of the many components of their "cultural package".

\section{Philippines}

Knowledge of intentional dental modification in the Philippines is taken from historical accounts, ethnographic writings, and the archaeological record. In sum, the common dental modification practices here involve filing, chipping, inlaying and plating, and blackening or staining through betel nut chewing (Rittershofer 1937; Atienza 2014). 
Atienza (2014) notes that several Chinese scholars and Spanish travelers documented encountering indigents - usually of high-status in their local communities - with modified teeth due to gold-pegging, filing, and coloring or staining. However, Spanish scholar Juan Francisco de San Antonio wrote that many Filipino indigents had abandoned (or were forced to) dental modification practices by the mid-eighteenth century (Rittershofer 1937).

Ethnographic accounts by the likes of Christie and Fox note the filing and sharpening of teeth among different members of the Subanuns and Negritos, respectively, as a sign of reaching maturity, as well as beauty and ornamentation and marking group identity (Atienza 2014). Cole similarly documented filing and blackening of teeth among the Bagobos, Manobos, Mandayas, and Tagakaolos when an individual reaches puberty, to signify their suitability and eligibility for marriage.

Archaeological evidence (Atienza 2014) for intentional teeth modification includes stained adult teeth recovered from Duyong Cave, part of the Tabon Cave Complex in the island of Palawan. The so-called "Bolinao Skull" from a $13^{\text {th }}-15^{\text {th }}$ century burial site up north in Pangasinan was deemed unique for the dental ornaments - gold plates with fish scale patterns - found on the six upper and lower anterior teeth of the skull. Gold pegging as a modification technique is associated with sites dating to the historical period of the Age of Contact and Trade.

In 1937, Rittershofer published his assessment of anterior teeth collected from different sites of Negros, Masbate, and Samar in the Visayas Islands. The teeth collection was rich in terms of modification techniques, including staining (likely due to betel nut), inlaying, and gold-pegging. A more recent excavation in Northern Mindanao saw the recovery of one nearly complete skeleton found with gold plates on several of the anterior teeth; Bernardo, one of the student excavators at the site, wrote an initial unpublished report of these findings, and it is hoped that more remains of similar kind will be discovered in future excavations on site.

Other sites in the Philippines where modified teeth have been recovered through archaeological excavation include Calatagan (Batangas), Sta Ana (Manila), Bulan (Sorsogon), Pila (Laguna), Marinduque, Samar, and Butuan (Atienza 2014). 


\section{Summary}

Previous literature has noted a distinct lack of widespread intentional dental modification during the Bronze Age of Southeast Asia, and this is once again seen in the data presented above. This is interesting as there's a prominence of intentional dental modification being practiced in both the Neolithic period and the Iron Age, but the Bronze Age that occurs in between them draws blanks (Domett et al. 2011). It is possible that this may be due to a lack of sufficient samples available across the region, so we do not rule out the possibility of intentional dental modification as a continuous practice among communities in Southeast Asia from the Neolithic period all the way to modern times.

In terms of geographic distribution of available evidence (Figure 1), there is significantly more sites in Mainland Southeast Asia where evidence of intentional dental modification has been observed. There is especially an abundance of sites in Cambodia and Thailand, as these have been extensively excavated and surveyed for intentional dental modification. It is hoped that future research looks into two things here: 1) explore other geographical areas of the mainland (e.g., Laos and Vietnam), and; 2) trace a more concrete path of the origin and rise of intentional dental modification practices in the Southeast Asian region. Given the evidence of sites in China with intentional dental modification dated to roughly 6000 or so years ago (Domett et al. 2011), there is still around 2000 years of discrepancy that needs to be accounted for in the origin story. Meanwhile, in Island Southeast Asia, most of the older prehistoric sites are only located in the different islands of Indonesia, with majority of the samples from the Philippines and Borneo associated with later (or even historic) periods.

The most common technique of intentional dental modification observed in prehistoric Southeast Asia is dental ablation, or the deliberate removal of several teeth. Roughly 13 Neolithic sites had evidence of deliberate teeth removal, later disappearing in the Bronze Age before briefly resurging in the Iron Age (4 sites). More often it was the maxillary dentition being removed, particularly the incisors, although in some extreme cases canines and even premolars were being deliberately extracted as well. Milner and Larsen (1991, from Kinaston et al. 2020) theorize that the anterior (front) teeth are frequently affected by dental ablation as they are what are first seen in an individual when speaking, smiling, or moving their mouth. The purpose for dental ablation is not as clear in the archaeological record, so we look to ethnographic accounts for leads on potential motives. In Borneo, indigent groups partake in this practice for reasons of practicality (i.e., resource-hunting) and prophylaxis (i.e., refined feeding method) (Jones 2001). 
The next most observed dental modification technique in prehistoric Southeast Asia is dental filing, seen primarily in Indonesia for the inner part of the region and in Cambodia (particularly the northwestern region) for the mainland (Koesbardiati et al. 2015; Newton and Domett 2017). A similar technique, dental sharpening, was only observed in sites ranging from the Neolithic to the Iron Age in Indonesia. The temporal distribution of dental filing is more equal, with an increase in the Iron Age compared to the Neolithic. Although not elaborated, patterns of dental filing (and dental ablation) highly varied per site, but a better assessment and review of the patterns' distributions across the region makes for a good future study understanding intra-regional interaction reflected in the adoption of select modification patterns and designs. Ethnographic accounts of present-day groups in Indonesia, Borneo, and the Philippines noted of intentional filing still being practiced today, often done together with the blackening or coloring of the affected teeth (Domett et al. 2011). Again, we look towards these same ethnographic accounts for starting points to theorize motivations for continuing to intentionally file dentition, and these usually have to do with signifying "rite of passage" into adulthood or marriageability, conforming to beauty standards, and maintaining oral health.

As mentioned, with dental filing often comes the coloring, staining, or dyeing of teeth. Staining, like as seen in the samples from Duyong Cave (Tabon) in the Philippines, as well as other ethnographic accounts of Island Southeast Asia, can be caused by the frequent chewing of betel nut (Zumbroich 2011; Jones 2001). A more permanent or extreme way to dye, color, or in some cases blacken the teeth would be through creating a mix paste out of select plants that contain coloring elements, this paste would then be placed on the teeth regularly (i.e., after daily meals). Teeth coloring was so prevalent that at the time of European colonization, it was described as a "universal device of permanently marking the body" (Zumbroich 2011:97). Although colonizers attempted to restrict indigents from continuing the practice as a way to conform with Western beauty standards of white teeth, there are still some present-day communities that regularly color and dye their teeth, such as the Higaonon-Banwaon ethnic group of southern Philippines (Zumbroich 2011) and the Dusuns of Borneo (Jones 2001). In his assessment of teeth blackening practices in Asia, Micronesia, and Melanesia, Zumbroich (2011) documents its use for medical purposes, particularly to help alleviate the pain that comes with filing one's teeth, as well as to maintain oral health (i.e., avoidance of dental caries). Additionally, he writes that there are specific species of plants that societies in these geographical areas tend to select for their medical teeth blackening practice, likely because the components in plants that activate blackening also contain medicinal benefits. 
Although rare in the findings mentioned above, one last technique of intentional dental modification observed in prehistoric Southeast Asia is the creation of plates to place on top of the teeth (usually the anterior ones); among the sites mentioned here, gold plating was observed only in the Philippines, in early historic sites (i.e., Age of Contact), although it's still possible that this tradition may have been done in other parts of the region and have simply not been uncovered just yet.

\section{Conclusion}

Intentional dental modification has been practiced widely not just in geographical distribution but also temporally. Its prevalence and continuity may have to do with Scott and Turner's (1997, from Koesbardiati et al. 2015) theory of the mouth acting as both a biological and a social organ, meaning that modifications done to the mouth (especially the teeth) reflect the community's values, beliefs, and cultural practices. Deliberate change or transfiguration of the teeth can be done in many ways, including chipping, filing, extraction, plating, inlaying, and coloring. Evidence of such practices can be seen not just in Southeast Asia, but also in other parts of the globe, including South America and Africa (Smith-Guzmán et al. 2020, Bonfiglioli et al. 2004; Mower 1999), and Europe (De Castro et al. 1988).

This paper sought to look at existing documentation of intentional dental modification in prehistoric Southeast Asia. Data reveals extensive research in some geographical areas and time periods, with some gaps, particularly for the Bronze Age in terms of temporality, and Laos, Vietnam, and Island Southeast Asia for geographical representation. Nonetheless, dental ablation, filing, coloring, and plating have prevailed throughout the archaeological record of the region, although why they were being practiced at all still requires support of ethnographical accounts to answer. Current theories include celebrating critical lifestages (i.e., puberty, marriage, mourning), conforming to community beauty standards, practicality to do daily tasks, and maintaining oral health. It is encouraged for future studies on intentional dental modification to always include in their assessment a contextualization of the ancient population health to review the impact of modification practices on community health, as we slowly detach ourselves from the old stereotype that these intentional methods of dental transfiguration only led to poor dentition and oral health. It would also be interesting to see how the variable of migration comes into play with the prevalence of dental modification practices, or the patterns distributed across the sites, i.e., does the entrance of migrants into a community mean they bring with them new modification techniques and patterns to assimilate into the welcoming group, or do the migrants and locals remain distinct in using their modification practices as a marker of self and group identity? 
As one of the few material evidences of body modification practices preserved in the archaeological record, studies of intentional dental modification are relevant as we continue to understand the cultural aspects of the lives of past humans, and assess the cultural (dis)continuity of these traditions into modern-day forms of body modification, art, healing, self-expression, and identity.

\section{Acknowledgements}

Utmost gratitude to Dr. Michael Herrera for the encouragement to not only write this paper, but also to share it to an audience outside of our classes over the pandemic. Special thanks as well to Jethro Malimata, Claudia Laud, and Arturo Tablan III for their support and fruitful insights from the initial drafts of this paper all the way to submission, and Anselmo Adriano V for the assistance in translations of the title and abstract to Filipino.

\section{References}

ASEAN UP (2016) 8 free maps of ASEAN and Southeast Asia. Available at:

https://aseanup.com/free-maps-asean-southeast-asia/ [accessed 1 March 2021].

Atienza, AA (2014) Early Aesthetic Dentistry in the Philippines: An Anthropological

Perspective. Acta Medica Philippina, 48(1): 68-72.

Barnes, DM (2010) Dental Modification: An Anthropological Perspective. Available at:

https://trace.tennessee.edu/utk_chanhonoproj/1345 [accessed 21 October 2021].

Bernardo, JC (2019) Pre-colonial Fad: A Look on the Gold Teeth from the Burail at the Calumat Open Site [Unpublished work].Archaeological Studies Program, University of the Philippines Diliman.

Coppa, A, Bondioli, L, Cucina, A, Frayer, DW, Jarrige, C, Jarrige, JF, Quivron, G, Rossi, M, Vidale, M and Macchiarelli, R (2006) Early Neolithic tradition of dentistry. Nature, 440: 755-756.

De Castro, JB, Bromage, TG and Jalvo, YF (1988) Buccal striations on fossil human anterior teeth: evidence of handedness in the middle and early Upper Pleistocene. Journal of Human Evolution, 17(4): 403-412.

Domett, KM, Newton, J, O'reilly, DJ, Tayles, N, Shewan, L and Beavan, N (2013) Cultural modification of the dentition in prehistoric Cambodia. International Journal of Osteoarchaeology, 23(3): 274-286.

Fastlicht, S (1948) Tooth mutilations in pre-columbian Mexico. The Journal of the American Dental Association, 36(3): 315-323.

González, EL, Pérez, BP, Sánchez, JS and Acinas, MMR (2010) Dental aesthetics as an expression of culture and ritual. British Dental Journal, 208(2): 77-80.

Jones, A (2001) Dental transfigurements in Borneo. British Dental Journal, 19(12): 98102. 
Kinaston, RL, Koesbardiati, T, Suriyanto, RA, Buckley, HR, Halcrow, SE, Foster, A, Simanjuntak, T, Bedford, S, Murti, DB, Putri, RS and Galipaud, JC (2020) Ritual tooth ablation and the Austronesian expansion: Evidence from eastern Indonesia and the Pacific Islands. The Journal of Island and Coastal Archaeology: 1-32.

Knudson, KJ and Buikstra, JE (2007) Residential mobility and resource use in the Chiribaya polity of southern Peru: strontium isotope analysis of archaeological tooth enamel and bone. International Journal of Osteoarchaeology, 17(6): 563580.

Koesbardiati, T, Murti, DB and Suriyanto, RA (2015) Cultural dental modification in prehistoric population in Indonesia. Bulletin of the International association for paleodontology, 9(2): 52-60.

Kusaka, S, Ando, A, Nakano, T, Yumoto, T, Ishimaru, E, Yoneda, M, Hyodo, F and Katayama, K (2009) A strontium isotope analysis on the relationship between ritual tooth ablation and migration among the Jomon people in Japan. Journal of Archaeological Science, 36(10): 2289-2297.

Mower, J (1999) Deliberate ante-mortem dental modification and its implications in archaeology, ethnography and anthropology. Papers from the Institute of Archaeology, 10: 37-53.

Newton, JS (2014) Health, diet and migration prior to the establishment of the pre-Angkorian civilisation of Southeast Asia. PhD thesis, James Cook University, Townesvillle.

Newton, J and Domett, K (2017) The biocultural context of dental modification in prehistoric Southeast Asia. In: SE Burnett and JD Irish (eds.) A World View of Bioculturally Modified Teeth. University Press of Florida.

Palefsky, G (2019) Tooth ablation in Iron Age central Thailand: Evidence from the archaeological sites of Ban Mai Chaimongkol and Tha Kae. International Journal of Osteoarchaeology, 29(5): 696-705.

Rittershofer, LF (1937) Gold decorated teeth from the Philippine Islands. Journal of Dental Research, 16(2): 123-133.

Smith-Guzmán, NE, Rivera-Sandoval, J, Knipper, C and Arias, GaS (2020) Intentional dental modification in Panamá: New support for a late introduction of African origin. Journal of Anthropological Archaeology, 60: 101226.

Willman, JC, Shackelford, L and Demeter, F (2016) Incisor ablation among the late upper paleolithic people of Tam Hang (Northern Laos): Social identity, mortuary practice, and oral health. American Journal of Physical Anthropology, 160(3): 519-528. 
Zumbroich, TJ (2011) To Strengthen the Teeth and Harden the Gums-Teeth blackening as medical practice in Asia, Micronesia and Melanesia. Ethnobotany research and applications, 9(4): 97-113.

Zumbroich, TJ (2009) The ethnobotany of teeth blackening in Southeast Asia. Ethnobotany Research and Applications, 7: 381-398. 